
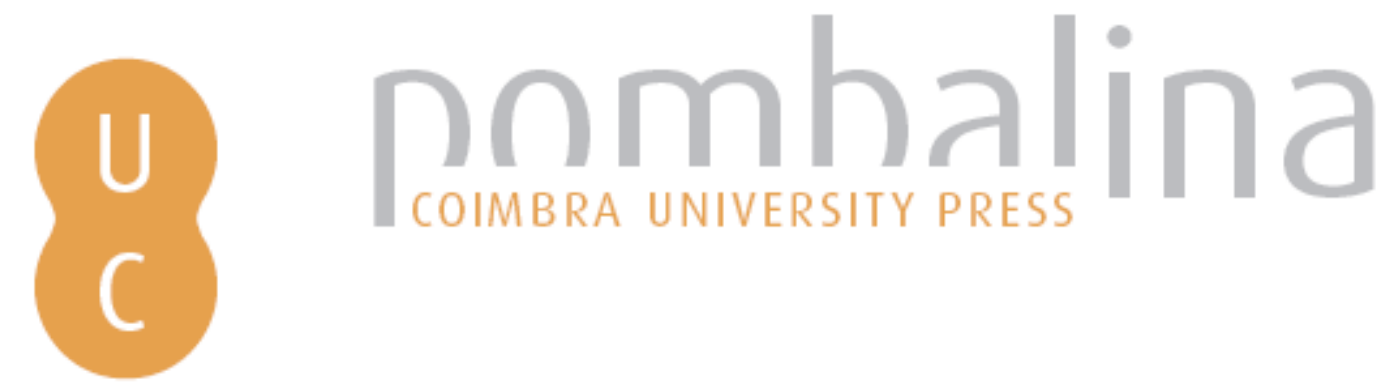

Monitoring post-fire forest regeneration of Pinus brutia in North Lebanon

Autor(es): $\quad$ Halabi, Amira El; Mitri, George; Jazi, Mireille

Publicado por: Imprensa da Universidade de Coimbra

URL

persistente:

URI:http://hdl.handle.net/10316.2/34195

DOI:

DOI:http://dx.doi.org/10.14195/978-989-26-0884-6_64

Accessed : $\quad$ 26-Apr-2023 12:31:42

A navegação consulta e descarregamento dos títulos inseridos nas Bibliotecas Digitais UC Digitalis, UC Pombalina e UC Impactum, pressupõem a aceitação plena e sem reservas dos Termos e Condições de Uso destas Bibliotecas Digitais, disponíveis em https://digitalis.uc.pt/pt-pt/termos.

Conforme exposto nos referidos Termos e Condições de Uso, o descarregamento de títulos de acesso restrito requer uma licença válida de autorização devendo o utilizador aceder ao(s) documento(s) a partir de um endereço de IP da instituição detentora da supramencionada licença.

Ao utilizador é apenas permitido o descarregamento para uso pessoal, pelo que o emprego do(s) título(s) descarregado(s) para outro fim, designadamente comercial, carece de autorização do respetivo autor ou editor da obra.

Na medida em que todas as obras da UC Digitalis se encontram protegidas pelo Código do Direito de Autor e Direitos Conexos e demais legislação aplicável, toda a cópia, parcial ou total, deste documento, nos casos em que é legalmente admitida, deverá conter ou fazer-se acompanhar por este aviso. 


\section{ADVANCES IN}

Forest Fire

\section{RESEARCH}

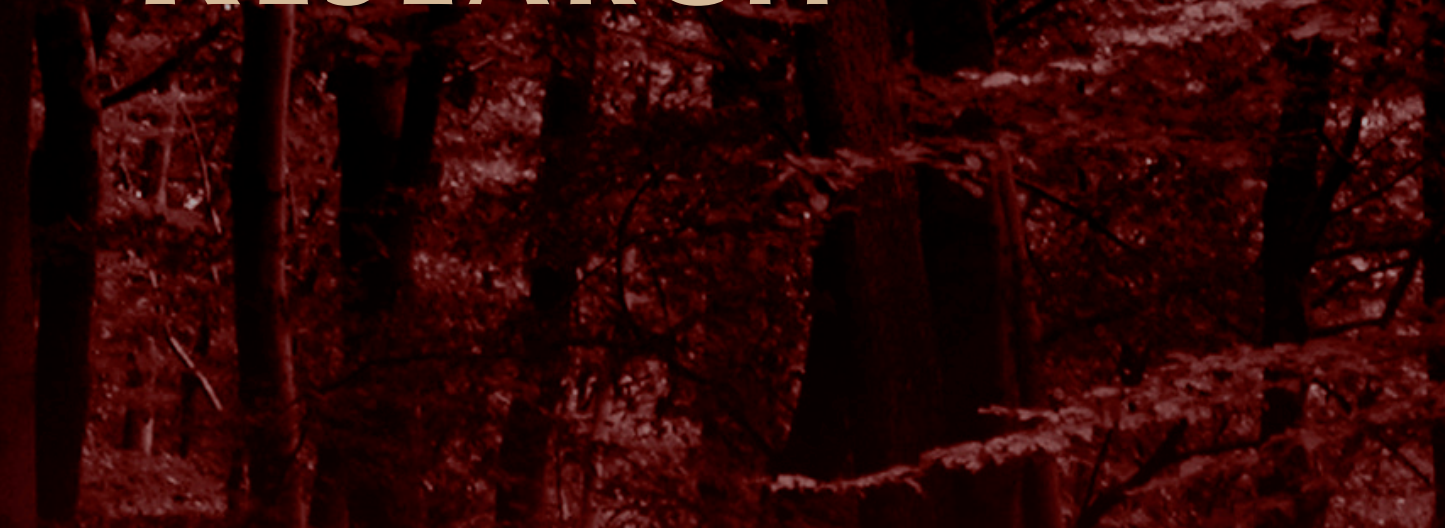

\section{DOMINGOS XAVIER VIEGAS}

\section{EDITOR}




\title{
Monitoring post-fire forest regeneration of Pinus brutia in North Lebanon
}

\author{
Amira El Halabi ${ }^{\mathrm{a}}$, George Mitri ${ }^{\mathrm{ab}}$, Mireille Jazi $^{\mathrm{b}}$ \\ ${ }^{a}$ Department of Environmental Sciences, Faculty of Sciences, University of Balamand, Lebanon. \\ ${ }^{b}$ Institute of the Environment, University of Balamand, Lebanon.george.mitri@balamand.edu.lb
}

\begin{abstract}
Forest fires represent a major threat to Lebanon's forests. More precisely, Pinus brutia forests, which occupy relatively large areas in Lebanon, are affected by frequent fire events. Lebanon's National Strategy for forest fire management highlighted the need to facilitate natural forest regeneration and undertake reforestation activities in areas where regeneration is not possible. Accordingly, this study aimed at assessing post-fire regeneration of Pinus brutia in the Mediterranean region of North Lebanon. A total of $540 \mathrm{samples}$ of $1 \times 1 \mathrm{~m}^{2}$ were collected on 18 different sites affected by fires throughout the past 20 years. The density of seedling regeneration was calculated for each plot. The highest regeneration density $\left(10.33\right.$ seedlings $\left./ \mathrm{m}^{2}\right)$ was observed on plots that were sampled one year after fire. The regeneration density decreased by $68 \%$ on plots sampled four years after fire when compared to plots sampled one year after fire. Also, the plots that were sampled five years after fire showed a $93.8 \%$ decrease in regeneration density. This continuous could be attributed to a high mortality rate due to prevailing severe weather conditions and human disturbances. The results highlighted the need to implement efficient post-fire management measures within the first four years after a fire event to decrease the mortality rate of young pine seedlings and to assist in the successful recovery of fire affected sites.
\end{abstract}

Keywords: forest fires, post-fire natural regeneration, Pinus brutia

\section{Introduction}

Lebanon's forest cover is a unique feature in the semi-arid environment of the Mediterranean. Lebanon's forests play an important role in supporting high biodiversity and providing a variety of environmental goods and services. Nevertheless, several biophysical and anthropogenic factors have shaped biodiversity in Lebanon (MOE/UNDP, ECODIT 2011).

Increasingly, fire occurrence risk was observed in association with high maximum temperatures and long dry seasons (Salloum and Mitri, 2014). Forest fires represent a major and continuous threat to Lebanon's forests (Mitri et al., 2014). In this context, monitoring post-fire regeneration of Pinus brutia is expected to support National efforts in restoring healthy ecological conditions of burned forest lands by providing useful and insightful information about the status of natural regeneration after fire (Mitri and Fiorucci, 2012).

Lebanon's National Strategy for forest fire management clearly indicated the need to facilitate natural forest regeneration and undertake reforestation activities in areas where regeneration is not possible (MOE/AFDC, 2009). Until present, Lebanon lacks comprehensive studies for assessing trends in postfire forest regeneration. Accordingly, the aim of this study was to assess post-fire regeneration of Pinus brutia in North Lebanon.

\section{Study area and dataset description}

Lebanon is situated on the eastern shores of the Mediterranean. The country is characterized by its Mediterranean climate with warm and dry summer and cool and wet winters. Forests in Lebanon cover around 139,376 ha which accounts for $13.3 \%$ of the Lebanese territory. Coniferous forests occupy 31 
$\%$ of the total forest cover (MOE/UNDP/ECODIT, 2011). More specifically, pine forests including Pinus pinea, Pinus brutia, and Pinus halepensis are mostly found on the western slopes of the Mount Lebanon chain and they are constantly affected by fire events.

During the year of 2013, sampling of Pinus brutia fire affected forests was conducted on 8 different fire sites located between $500 \mathrm{~m}$ and $1000 \mathrm{~m}$ above sea level in North Lebanon (Table 1). A total of 540 samples of $1 \times 1 \mathrm{~m}^{2}$ were collected and the number and height of seedlings was recorded for each sample. Historical weather data showed that around $95 \%$ of the annual precipitation fall between October and April. The average rainfall in this region has an average $1210 \mathrm{~mm}$ per year (MOE/UNDP/ECODIT, 2011).

Table 1. Characteristics of fire affected sites

\begin{tabular}{|l|l|l|l|}
\hline $\begin{array}{l}\text { Year } \\
\text { fire }\end{array}$ & Slope percent & Elevation (m) & Aspect \\
\hline 1993 & 30 & 703 & North East \\
\hline 2004 & 5 & 710 & West \\
\hline 2006 & 45 & 722 & South \\
\hline 2007 & 30 & 794 & North west \\
\hline 2007 & 10 & 416 & South west \\
\hline 2008 & 15 & 642 & North East \\
\hline 2009 & 30 & 670 & South east \\
\hline 2012 & 45 & 1139 & North east \\
\hline
\end{tabular}

\section{Methods}

\subsection{Field sampling}

The field sampling comprised surveying 20x20m plots. Each plot comprised three different locations of sampling across the slope (namely, top, middle, and bottom). A total of 30 samples of $1 \mathrm{~m}^{2}$ were collected within each plot using the belt transect sampling method. The length of the belt transect was 20 meters and the sampling interval was 5 meters. A quadrat of $1 \mathrm{~m} \mathrm{x} 1 \mathrm{~m}$ was placed on each side of the line at the interval level. Accordingly, the number and height of individual seedlings were collected.

\subsection{Statistical analysis of field data}

The calculation of the regeneration density was developed based on the number of seedlings per square meter (Equation 1), an approach that was also used by Titsoni (1997).

$$
\frac{\sum \text { number of seedlings }}{\text { Total number of plots }}
$$

Equation 1

Consequently, the variation in the post-fire regeneration density of Pinus brutia based on descriptive statistics, and the average regeneration density was calculated for each year. ANOVA-stepwise analysis was applied to investigate significant changes in regeneration density and height of seedlings throughout the years.

\section{Results and discussion}

The highest regeneration density (average of 10.33 seedlings $/ \mathrm{m}^{2}$ ) was recorded on plots that were surveyed one year after fire. This could be attributed to seed availability on site and lack of long-term natural stresses and human disturbances (Figure 1). 
Sites surveyed three years after fire showed a decreased density by $68 \%\left(7.11\right.$ seedlings $\left./ \mathrm{m}^{2}\right)$ when compared to the results of sites surveyed one year after fire. Following the same comparison approach, sites sampled five years after fire showed an abrupt decrease in the regeneration rate $(0.44$ seedlings $/ \mathrm{m}^{2}$ ), while sites sampled six years after fire showed only 0.22 seedlings $/ \mathrm{m}^{2}$. These gradual decreases in regeneration density could be attributed to both environmental and anthropogenic conditions including severe climatic conditions, human disturbances, and the effect of local environmental characteristics of the sites. Other factors such as fire characteristics (fire severity), could also affect regeneration density of Pinus brutia (Pausas et al., 2008).

Finally, the results from plots sampled twenty years after fire showed a regeneration density of 1 seedling $/ \mathrm{m}^{2}$. This could be attributed either to insignificant variation in regeneration density or to a continuous enrichment of young seedlings from the surrounding forested areas (Tsitsoni, 1997).

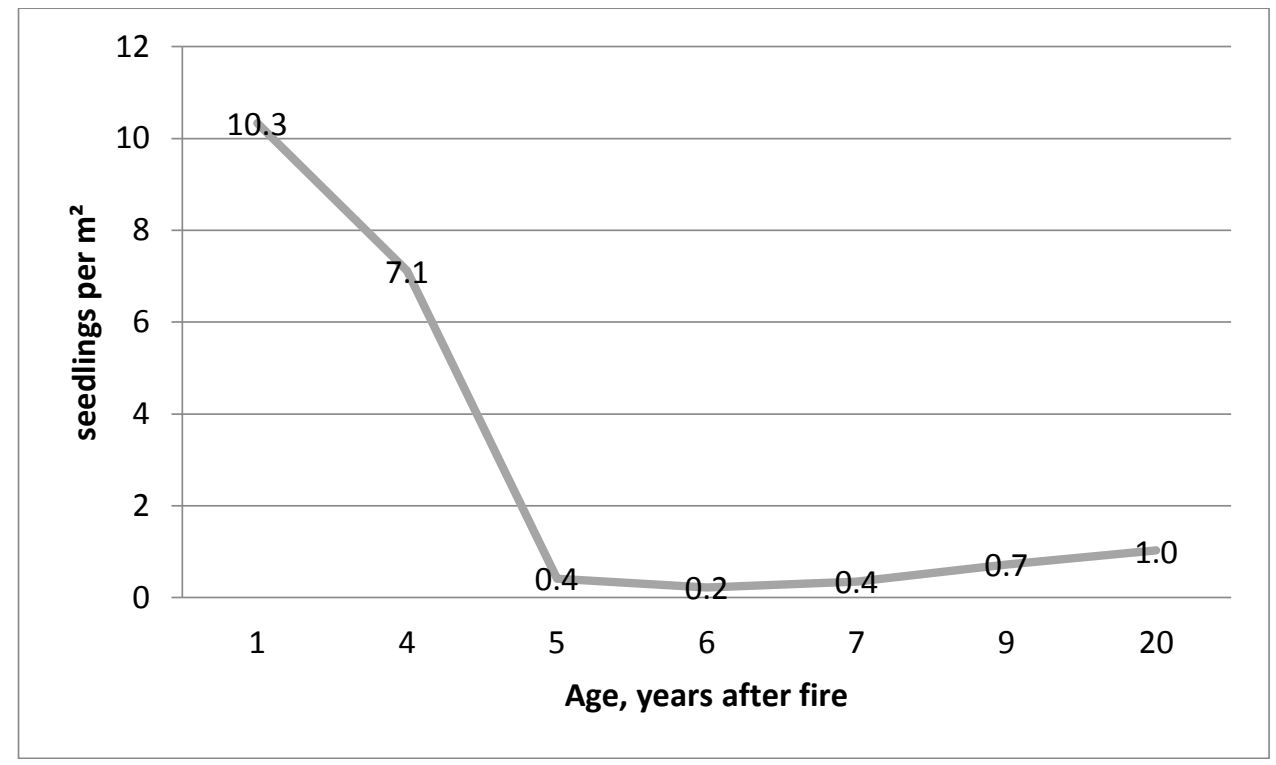

Figure 1. Multi-temporal rate of regeneration density of Pinus brutia

The regression analysis showed post-fire average height increment of $9.26 \mathrm{~cm}$ (Figure 2), while other studies in the Mediterranean showed an average growth of 5-20 cm per year (Neyisci, 1989; Thanos et al., 1989; Spanos, 1994; Spanos el al., 2000). 


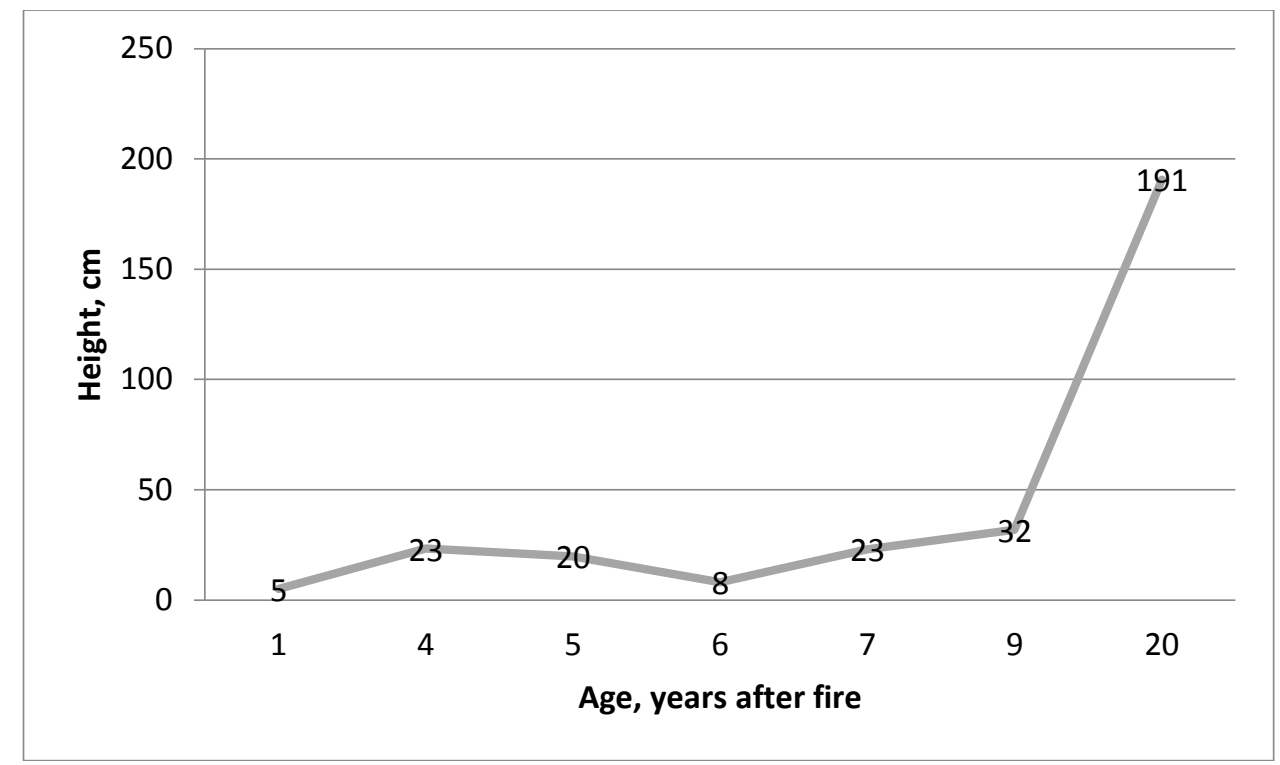

Figure 2 Post-fire variation of average seedling height

\section{Conclusions}

The highest regeneration density $\left(10.33\right.$ seedlings $\left./ \mathrm{m}^{2}\right)$ was observed on plots that were sampled one year after fire. When compared to plots sampled five years after fire, the regeneration density abruptly decreased to 0.44 seedlings $/ \mathrm{m}^{2}$.

In the light of these findings, it is essentially important to invest more post-fire restoration efforts in assisting natural regeneration in order to promote natural recovery of pine burned forests. The implementation of certain protection measures during the first two years after a fire event is expected to facilitate a higher survival rate of established seedlings. This is expected to be a cost saving initiative in comparison to costly reforestation campaigns.

Future work will involve conducting further studies to understand the different factors that affect the natural regeneration of pine forests in Lebanon as an attempt to come out with improved post-fire management initiatives.

\section{Acknowledgments}

The authors would like to thank the Lebanon Reforestation Initiative (LRI) (a project funded by the United States Agency for International Development (USAID) and implemented by the US Forest Service (USFS) for their financial support to the conducted work. The contents do not necessarily reflect the views of USAID or the United States Government.

\section{References}

Mitri, G. and Fiorucci, P. (2012). Towards monitoring post-fire vegetation cover dynamics in the Mediterranean with the use of object-based image analysis of Landsat images. In. 1st Workshop on Temporal Analysis of Satellite Images (Ban, Y., Ed.), (pp. 2 -25). Mykonos Island, Greece: European Association of Remote Sensing Laboratories.

Mitri, G., Jazi, M., and McWethy, D. (2014). Investigating temporal and spatial variability of wildfire potential with the use of object-based image analysis of downscaled global climate models. SouthEastern European Journal of Earth Observation and Geomatics, 3(2S), 251-254. 
MOE/AFDC. (2009). Lebanon's National Strategy for Forest Fire Management. (Mitri, G. Ed.). Beirut, Lebanon: Association for Forests, Development and Conservation.

MOE/UNDP/ECODIT. (2011). State and trends of the Lebanese environment. Beirut, Lebanon: ECODIT.

Neyisci, O. (1989). Effects of prescribed burning on soil chemical properties and subsequent seedling growth in Pinus brutia Ten. ecosystems (in Turkish). Turkish Forest Research institute: Technical Bulletin, 225, 1-56.

Pausas, J. G., Llovet,J., Rodrigo, A. and Vallejo, R. (2008). Are wildfires a disaster in the Mediterranean basin? A Review. International Journal of Wildland Fire, 17, 713-723.

Salloum, L. and Mitri, G. (2014). Assessing the temporal pattern of fire activity and weather variability in Lebanon. International Journal of Wildland Fire, 23(4), 503-509.

Spanos, E. A. (1994) Natural Regeneration of Pinus brutia in north-west areas of Thanos Island, burned in 1989 (in Greek). Geotechnika Epistimonika Themata, 4, 33-39.

Spanos, I., Daskalakou, E., and Thanos, C. (2000). Postfire, natural regeneration of Pinus brutia forests in Thasos Island, Greece. Actaoecologica, 21(1), 13-20.

Thanos, C.A., Marcou, A., Christoduoulakis, D., and Yannitsaros, A. (1989). Early post-fire regeneration in Pinus brutia forest ecosystems of Samos Island (Greece), ActaOecological, 10, 79 94.

Tsitsoni, T. (1997). Conditions determining natural regeneration after wildfires inI the Pinus halepensis (Miller, 1768) forest of Kassandra Peninsula (North Greece). Forest Ecology and Management, 92, 199-208. 